\title{
Seasona Variations in Physico-Chemical of Imo River
}

\author{
${ }^{1}$ Okorie, D.O and ${ }^{2}$ Nwosu, P.O \\ ${ }^{I}$ Department of Chemistry, Michael Okpara University of Agriculture, Umudike, Abia State \\ ${ }^{2}$ Soil Science Laboratories, National Root Crops Research Institute, Umudike, Abia State
}

\begin{abstract}
Physico-chemical properties of Imo River were determined from source to tributaries between 2007 and 2008 to ascertain the influence of urbanization and farm practices on the river. The physic-chemical parameters determined were $\mathrm{pH}$, Total hardness, Biological Oxygen Demand (BOD), Dissolved Oxygen (DO), Chemical Oxygen Demand (COD), Chloride $\left(\mathrm{Cl}^{-}\right)$, Bicarbonate $\left(\mathrm{HCO}_{3}^{-}\right)$, Nitrate $\left(\mathrm{NO}_{3}^{-}\right)$, Sodium $(\mathrm{Na})$, Potassium (K), Calcium (Ca) and Magnesium (Mg). Of all the pollution indices studied, the most pronounced were the $p H, B O D, D O$ and $C O D$. The river was found to be acidic at all season ( $p H$ ranged from $5.15-6.95$ ). However, this level of acidity is tolerable to aquatic life. Dissolved oxygen was most often, dangerously low $\left(2.51-16 \mathrm{mg} / \mathrm{dm}^{3}\right)$. BOD of $2.5-7.45 \mathrm{mg} / \mathrm{dm}^{3}$ has put a strain on aquatic life. Total hardness of $9.10-40.91$ $\mathrm{mg} / \mathrm{dm}^{3}$ limits the use of the water as a domestic water source. The significance of the entire result to the public health practitioners and the Federal Environmental Protection Agency (FEPA) is now obvious since the people who live along the river are now aware that treatment of such water is a matter of necessity.
\end{abstract}

Keywords: Physico-chemical, urbanization, farming practice, public health.

\section{Introduction}

Imo River sources in Umuaku village in Isuochi Local Government Area, Southeast of Abia State in South-east geopolitical area of Nigeria enters the Atlantic Ocean through several tributaries in Rivers State in the south-south geopolitical zone (Okonko et al., 1997). The spring starts from the rock and gradually increases in volume as other rivers and stream flow into the main channel (Edema et al, 2001, Relief Map of Abia State). It supplies water for daily activities of the people who life along its banks and tributaries.

The river exists clean only briefly and it's immediately polluted by prevailing environmental factors and human activities, thus it is possible for a river to be polluted by diesel from pleasure boats, fertilizers and biocides from agricultural and a whole variety of industrial effluent (Raymon, 1992). An USEPA (1986) report reveals that river pollution is particularly worse where a river passes cities and the most widespread contamination is from human excreta and sewage.

Industrialized countries have well-established agencies that monitor environmental pollution and set up guidelines for the disposal of industrial waste. Here in Nigeria, the Federal Environmental Protection Agency (FEPA) has been charged with the responsibility of policing the environment from pollution, and proffering solutions to endemic areas.

Several works exist in the chemical literature on river pollution studies in the south-east geopolitical zone of Nigeria. Khan (1982), Ogbukogu $(1984,1986)$ have provided some data for some rivers, springs and industrial effluents in the Anambra area, but these data are no longer relevant because they are outdated. Durugbo (1980), Emezie (1980), Nwadiaro (1985a, 1985b) have worked on the many water resources scattered around Imo State. Obodo $(2001,2002)$ have worked on the Rivers Nworie, Otamiri, Imo, Aba, Mbaa and the lower Niger.

The objective of the present study is to monitor the changes in the physico-chemical properties of this very important river that links three major states in Southeastern Nigeria and beyond.

\section{(a) Collection of Samples}

\section{Materials And Methods}

Sampling was carried out from April 2007 through March 2008 covering both the rainy and dry season. Water samples were collected from depths $20 \mathrm{~cm}$ as described in the Standard Methods of Examination of Water and Waste Water. The samples were taken at points where the compositions were demonstrably homogenous and away from disturbing influences. After thoroughly mixing, by swirling, analytical samples were drawn from the mixture, preserved with concentrated hydrochloric acid and stored at $4^{\circ} \mathrm{C}$ before use.

\section{(b) Study Area}

The River sources from Umuaku ( $\left.\mathrm{SP}_{1}\right)$ in Umunneochi Local Government Council of Abia State and traverses Imo State from where the state derives it name: The River is bridged at Okigwe $\left(\mathrm{SP}_{3}\right)$, Ekenobizi, at the outskirts of Umuahia $\left(\mathrm{SP}_{4}\right)$, Owerrinta $\left(\mathrm{SP}_{5}\right)$ and Obigbo at the outskirts of Port-Harcourt, the capital of 
Rivers State. Furthermore, samples were collected at estimated mid-points between $\mathrm{SP}_{1}$ and $\mathrm{SP}_{3}$ and $\mathrm{SP}_{4}$ and $\mathrm{SP}_{5}$ and $\mathrm{SP}_{6}$.

\section{(C) Analysis}

The acidity, alkalinity, carbon dioxide and dissolved oxygen were determined by titrimetric methods, $\mathrm{pH}$ by $\mathrm{pH}-$ metre, ammonia and ammonia nitrogen by calorimetric methods. Total hardness, Calcium and Magnesium hardness were estimated by complexometric methods with EDTA. Chloride was measured by argentometric method following Mohr's method. Colour, phosphate, sulphate, iron and nitrate were measured by spectrophotometric methods using Unicam SP 500 UV-visible spectrophotometer (manufactured in Great Britain). Total solids dried at 103 degrees, and conductivity of water were measured by the difference in weight method and the conductivity meter respectively-all according to APHA-AWWA-WPCF (1989), Theroux et al., (1943), Wolcher (1943) and Sandel (1959). The $\mathrm{pH}$ and temperature were determined on the spot, while carbon dioxide was determined subsequently.

\section{Results And Discussion}

The results of the physico-chemical analysis are shown in Table 1 and 2. The temperature ranged from $26.6^{\circ} \mathrm{C}$ in the dry season to $31.6^{\circ} \mathrm{C}$ in the rainy season. The high temperature in the rainy season induces latent heat of vaporization from the surface and thus leaves it cooler. The colour of the surface water appears clearer during the dry seasons than the rainy season. The colour ranges from 5.30 Hazen Units in the dry season to 40.21 Hazen Units in the rainy season. The reasons for this is the muddy flood water which empties into the river during the rainy season, and this settles at the dry season leaving clearer water above. Brown colour observed is mainly due to the presence of $\mathrm{Fe}^{+3}$. This attribute is not good, at least, for aesthetic reason. Under natural conditions any $\mathrm{Fe}^{+2}$ present in the water is oxidized to $\mathrm{Fe}^{+3}$. The brown colouration also makes them unsuitable for any other purpose except for block making. Water is considered portable when it has colour of less than 5 Hazen Units (WHO, 1984, HACH, 1981; Cox, 194).

Conductivity is generally low around the source than elsewhere, indicating that the water does not contain too much of ions. In general the conductivities are lower in the rainy than in the dry season. The lower values for rainy season are attributed to dilution by rain water and incoming flood. The comparatively higher values of $\mathrm{SP}_{3}$, to $\mathrm{SP}_{7}$ could be as a result of flood entering into the river picking more ions as it does so

The levels of sodium and potassium are generally low with sodium being appreciably higher than potassium in all the points sampled. The probable reason for this is the predominance in $\mathrm{NaCI}$ in the underlying rocks as well as sea water intrusion. The dry season levels of sodium and potassium are generally lower than the rainy season. The higher values for the rainy season are attributed to flooding with its concomitant deposition of all manner of substance, $\mathrm{Na}^{+}$and $\mathrm{K}^{+}$inclusive.

The major anions; $\mathrm{HCO}_{3} ; \mathrm{NO}_{3} ; \mathrm{CI}$ and $\mathrm{PO}_{4}{ }^{3-}$ show a more appreciable difference between the seasons and are generally high during rainy season. Although low, the phosphate levels are high enough to support aquatic life. A high concentration, though, would cause eutrophication, especially in the presence of high nitrate levels. The consequence of this lowering of dissolved oxygen content of the river is the death and decay of vegetation.

There were no detectable sulphates throughout the two seasons. This lends credence and confirms the assertion of Nriagu (1986a) who observed a similar trend for River Niger.

The nitrate and phosphate show a definite trend. No doubt, the higher level observed for the rainy season is due to contributions from agricultural farms scattered along its course which eventually empty into the River. The same is observed for phosphate. Unexpectedly, the phosphate levels obtained in this work did not show much variation between the seasons in spite of phosphate being an essential part of NPK fertilizer, a popular brand of fertilizer in the eastern states. The observed $\mathrm{pH}$ values 5.15-6.95 are tolerable to aquatic lives and within World Health Organization (WHO) limits. In general, the river is more acidic during the dry season than the rainy season and never alkaline at any time of the year. Flooding and putrefaction of decaying organic matter could be responsible for this. The $\mathrm{pH}$ of the river varies from 5.15 in the dry season at its tributaries to 6.95 at source. Surprisingly there do not appear to be much fishing activities in this river. The total dissolved solids (TDS) as well as total suspended solids (TSS) are higher in Imo-River during the dry season and generally increase downstream. The higher values for the dry season are due to evaporation. The dissolved oxygen observed for Imo-River varies from 2.50 to 8.50 . A comparison between rainy and dry season does not show a definite tend.

The total hardness is approximately the sum of the calcium and magnesium hardness. Total hardness also increases downstream but generally low, in fact less than $60 \mathrm{mg} / \mathrm{dm}^{3}$. This makes the water all season portable (Sawyer and McCart, 1967, Othiner, 1970), and particularly suited for laundry.

The oil and greased observed were understandably high especially in the rainy season. The banks of the river are the site of purifying wastes which are washed to the river by flood. 
Table 1: Physico-Chemical Characteristics of Imo River in the Rainy Season

\begin{tabular}{|c|c|c|c|c|c|c|c|}
\hline VARIABLE & $\mathbf{S P}_{1}$ & $\mathbf{S P}_{2}$ & $\mathbf{S P}_{3}$ & $\mathbf{S P}_{4}$ & $\mathbf{S P}_{5}$ & $\mathbf{S P}_{6}$ & $\mathbf{S P}_{7}$ \\
\hline TEMPERATURE $\left({ }^{0} \mathrm{C}\right)$ & 30.5 & 29.9 & 31.6 & 29.8 & 30.7 & 30.1 & 30.7 \\
\hline pH & 6.95 & 6.87 & 6.77 & 6.01 & 6.65 & 6.60 & 6.50 \\
\hline Sulphate (mg/dm³) & NOT DETECTED & & & & & & \\
\hline COLOUR (Hazen Unit) & 8.30 & 10.36 & 24.25 & 30.35 & 35.30 & 21.62 & 40.21 \\
\hline TOTAL HARDNESS $\left(\mathrm{mg} / \mathrm{dm}^{3}\right)$ & 9.10 & 13.30 & 22.60 & 36.90 & 36.53 & 35.45 & 32.59 \\
\hline Ca HARDNESS $\left(\mathrm{mg} / \mathrm{dm}^{3}\right)$ & 4.60 & 7.10 & 11.20 & 11.65 & 16.45 & 10.15 & 16.10 \\
\hline Mg HARDNESS (mg/dm $\left.{ }^{3}\right)$ & 5.50 & 6.15 & 16.50 & 14.05 & 20.11 & 11.14 & 20.15 \\
\hline Oil and Grease $\left(\mathrm{mg} / \mathrm{dm}^{3}\right)$ & 1.51 & 2.05 & 4.40 & 6.42 & 2.64 & 4.44 & 8.15 \\
\hline $\operatorname{TDS}\left(\mathrm{mg} / \mathbf{d m}^{3}\right)$ & 15.75 & 20.53 & 22.50 & 40.18 & 41.5 & 41.62 & 60.17 \\
\hline TSS (mg/dm $\left.{ }^{3}\right)$ & 20.16 & 14.30 & 30.17 & 38.41 & 40.18 & 19.41 & 20.17 \\
\hline BODS $\left(\mathrm{mg} / \mathrm{dm}^{3}\right)$ & 4.05 & 4.90 & 2.51 & 4.65 & 4.31 & 2.89 & 6.42 \\
\hline $\operatorname{COD}\left(\mathrm{mg} / \mathrm{dm}^{3}\right)$ & 20.15 & 19.65 & 30.65 & 30.45 & 25.65 & 19.45 & 22.40 \\
\hline $\mathrm{DQ}\left(\mathrm{mg} / \mathbf{d m}^{3}\right)$ & 2.51 & 3.56 & 4.16 & 3.61 & 3.09 & 3.56 & 4.16 \\
\hline Chloride & 1.32 & 1.84 & 1.96 & 4.50 & 4.90 & 10.16 & 10.16 \\
\hline
\end{tabular}

Table 2: Physico-Chemical Characteristics of Imo River in the Dry Season

\begin{tabular}{|c|c|c|c|c|c|c|c|}
\hline VARIABLE & $\mathbf{S P}_{1}$ & $\mathbf{S P}_{2}$ & $\mathbf{S P}_{\mathbf{3}}$ & $\mathbf{S P}_{4}$ & $\mathbf{S P}_{5}$ & $\mathbf{S P}_{6}$ & $\mathbf{S P}_{7}$ \\
\hline TEMPERATURE ( $\left.{ }^{0} \mathrm{C}\right)$ & 29.6 & 29.5 & 30.7 & 28.0 & 30.7 & 26.6 & 29.9 \\
\hline pH & 6.50 & 6.65 & 6.62 & 5.99 & 5.65 & 5.01 & 5.15 \\
\hline Sulphate $\left(\mathrm{mg} / \mathbf{d m}^{3}\right)$ & NOT DETECTED & & & & & & \\
\hline COLOUR (Hazen Unit) & 5.35 & 8.60 & 12.85 & 18.20 & 20.18 & 11.20 & 18.64 \\
\hline TOTAL HARDNESS $\left(\mathrm{mg} / \mathrm{dm}^{3}\right)$ & 11.15 & 14.05 & 28.55 & 40.91 & 30.51 & 36.25 & 21.06 \\
\hline Ca HARDNESS $\left(\mathrm{mg} / \mathrm{dm}^{3}\right)$ & 5.05 & 6.45 & 12.50 & 15.51 & 12.05 & 16.31 & 11.45 \\
\hline Mg HARDNESS (mg/dm $\left.{ }^{3}\right)$ & 6.10 & 7.50 & 15.65 & 21.40 & 18.05 & 19.14 & 21.41 \\
\hline Oil and Grease $\left(\mathrm{mg} / \mathrm{dm}^{3}\right)$ & 1.40 & 2.00 & 10.11 & 5.14 & 2.05 & 7.74 & 6.45 \\
\hline TDS $\left(\mathrm{mg} / \mathbf{d m}^{3}\right)$ & 20.60 & 25.61 & 30.16 & 26.18 & 35.06 & 48.16 & 65.71 \\
\hline TSS $\left(\mathbf{m g} / \mathbf{d m}^{3}\right)$ & 12.65 & 21.14 & 26.15 & 19.53 & 30.12 & 26.16 & 19.61 \\
\hline BODS $\left(\mathrm{mg} / \mathrm{dm}^{3}\right)$ & 4.85 & 4.88 & 3.05 & 4.13 & 3.65 & 3.12 & 7.41 \\
\hline $\operatorname{COD}\left(\mathrm{mg} / \mathrm{dm}^{3}\right)$ & 20.16 & 21.42 & 31.45 & 30.05 & 16.69 & 21.62 & 20.50 \\
\hline $\mathrm{DQ}\left(\mathrm{mg} / \mathrm{dm}^{3}\right)$ & 2.61 & 3.18 & 4.03 & 3.76 & 2.61 & 3.21 & 4.00 \\
\hline Chloride & 2.01 & 2.06 & 2.11 & 5.01 & 10.46 & 8.17 & 11.64 \\
\hline
\end{tabular}

\section{References}

[1]. Cox, C.R. (1964). Operation and Control of Water Treatment Processes, WHO, Geneva, 172-182.

[2]. Edema, M. O., Omumu, R.S. and Fapetu, O.M. (2001). Microbiology and Physico-chemical Analysis of Different Sources of Drinking Water in Abeokuta. Nigeria Journal of Microbiology, 15(1): 57-61.

[3]. Emezie, N.O (1980). Problems of Water Supply in Nkwerre. B. Sc Thesis, Geography Department, University of Nigeria, Nsukka.

[4]. HACH (1984). Water Analysis Handbook; DR 3 and DREL/5.

[5]. Khan, H.U. (1982). Industrial Waste Characteristics in Anambra State, Nigeria. Management of Industrial Waste Water in Developing Nations.

[6]. Nriagu, J.O. (1986a). Chemistry of the River Niger 1, major: The Science of the Total Environment, 58:8-88.

[7]. Nwadiaro, C. S. and Orji, E. O. (1985a). Phytoplankton Productivity and Chlorophyll-a concentration of Oguta Lake in S. E. Nigeria. Hydrobiol. Bull., 19(2): 123-131.

[8]. Nwadiaro, C. S. and Umeham, S. N. (1985b). The Chemical Hydrology of Oguta Lake, Imo State, S. E. Nigeria. Arch. Hydrobiol., 105(2): 251-269.

[9]. Obodo, G.A. (2001). Toxic Metals in River Niger and its Tributaries. Journal IAEM, Vol. 28, $147-157$.

[10]. Obodo, G.A. (2002). Pollution Estimates of Rivers Nworie, Otamiri, Imo, Aba and Mbaa. The Physical Scientist, Vol. No. 1:27-33.

[11]. Ogbukogu, I. K. N. (1984). Hydrology and Chemistry of Surface and Groundwater Resources of Aguata Area, S. E. Nigeria Journal of African Earth Sciences, No. 2, 109-117.

[12]. Okonko, J.O, Adejoye, O.D. and Ogunusi, T. A. (2007). Physico-chemical Analysis of Different Water Samples used for Domestic Purpose in Abeokuta and Ojota, Lagos State, Nigeria. African Journal of Biotechnology, Vol. 7(5): 617-621.

[13]. Raymond, F. (1999). Problems of Water. EB and Sons Ltd., UK. Pp. 123-126.

[14]. Sawyer, C.N. and McCarty, P.L. (1967). Chemistry for Sanitary Engineers, McGraw-Hill Book Co., New York, 518p.

[15]. USEPA (1988). National Primary Drinking Water Regulation for Lead and Copper. Federal Register, 53: 31515-31578.

[16]. World Health Organization (WHO) (1984). International Standard for Drinking Water, $3^{\text {rd }}$ ed. WHO, Geneva. 